ВЕСТНИК ПНИПУ. ГЕОЛОГИЯ. НЕФТЕГАЗОВОЕ И ГОРНОЕ ДЕЛО

BULLETIN OF PNRPU. GEOLOGY. OIL \& GAS ENGINEERING \& MININC

ISSN 2224-9923

ToM/Volume 15 №20 2016

http://vestnik-pstu.ru/geo/

УДК 622.279.72:548.562

Article / Статья

(C) PNRPU / ПНИПУ, 2016

\title{
FEATURES OF SINGLE- AND MULTICOMPONENT GAS HYDRATES FORMATION
}

\author{
E.P. Zaporozhets, N.A. Shostak
}

Kuban State Technical University (2 Moskovskaya str., Krasnodar, 350072, Russian Federation)

\section{ОСОБЕННОСТИ ГИДРАТООБРАЗОВАНИЯ ОДНО- И МНОГОКОМПОНЕНТНЫХ ГАЗОВ}

\section{Е.П. Запорожец, Н.А. Шостак}

Кубанский государственный технологический университет (350072, Россия, г. Краснодар, ул. Московская, 2)

Received / Получена: 09.06.2016. Accepted / Принята: 29.08.2016. Published / Опубликована: 30.09.2016

Key words:

gas, hydrate cavity, hydrate formation, hydrate forming system, hydrates, crystalline structures, ice-like associates, multi-component gases, one component gases, molecular absorption, thermobaric conditions, manmade hydrates, hydrate cavities formation, crystalline structures formation, ice-like associates formation.
Ключевые слова: газ, гидратные полости, гидратообразование, гидратообразующая система, гидраты, кристаллические структуры, льдоподобные ассоциаты, многокомпонентные газы, однокомпонентные газы, поглощение молекул, термобарические условия, техногенные гидраты, формирование гидратных полостей, формирование кристаллических структур, формирование льдоподобных ассоциатов.

\begin{abstract}
Natural hydrates are a form of the gas existence in depths and a promising source of hydrocarbon gas. Manmade hydrates in bottom-hole zones and wellbores complicate hydrocarbon production, reducing production rates. In oil and gas collection systems hydrates are deposited under certain conditions of temperature and pressure on the walls of the pipes and increase its hydraulic resistance, thereby increasing energy consumption. The presence of hydrates in streams of producing fluid increases the wear of prefabricated collectors, reducing their life. In hydrocarbon field preparation`s systems (heat exchange equipment, separators, throttle devices, ejectors) hydrate deposition degrades technological processes. Hydrate formation in machinery and equipment (compressor, expander) collection and treatment systems lead to accidents. In gas pipeline transport the hydrate deposition reduces its effectiveness. To solve problems associated with technogenic hydrates and gas production from natural hydrates, it is necessary to know the basic features of their formation.

The article contains modern concepts of single- and multi-component gashydrates formation (natural and oil), which occur in natural and technical systems. Authors hope that the paper will be useful to a wide range of readers, especially students and staff of higher education institutions of oil and gas profile, as well as professionals, industrial activity of whom is connected with production, collection, preparation and transportation of natural and oil gases.

Based on the systematization and analysis of more than a thousand experimental research and practical applications in this area over the period since 1780 to the present time, the authors have identified some features of the hydrate formation from single or multi-component gases.
\end{abstract}

\begin{abstract}
Природные гидраты являются одной из форм существования газа в недрах Земли и перспективным источником углеводородного газа. Оценка техногенных гидратов в нефтяной и газовой промышленности в основном негативна. Их отложение в призабойных зонах и стволах скважин осложняет добычу углеводородов, уменьшая их дебиты. В системах сбора нефти и газа гидраты при определенных термобарических условиях отлагаются на стенках трубопроводов и повышают их гидравлическое сопротивление, тем самым увеличивая энергетические затраты. Присутствие гидратов в потоках извлекаемого из недр флюида повышает износ сборных коллекторов, уменьшая их ресурс. В установках промысловой подготовки углеводородов (например в теплообменном оборудовании, сепараторах, дросселирующих устройствах, эжекторах) гидратоотложение ухудшает технологические процессы. Образование гидратов в машинах и агрегатах (например компрессорных, детандерных) систем сбора и подготовки приводит к авариям. В трубопроводах, транспортирующих углеводородные газы, отложение гидратов уменьшает эффективность работы. Для решения проблем, связанных техногенными гидратами, а также для разработки технологий и техники добычи газа из природных гидратов необходимо знать основные особенности их образования.

Статья содержит современные представления о гидратообразовании одно- и многокомпонентных газов (природных и нефтяных), которые встречаются в природных и технических системах. На основании систематизации и анализа более тысячи экспериментальных исследований и практических приложений в этой области за период с 1780 г. и по настоящее время авторы выявили некоторые особенности образования гидратов из одно- и многокомпонентных газов.
\end{abstract}

Evgenii P. Zaporozhets (Author ID in Scopus: 6602575771) - Doctor of Technical Sciences, Professor of the Department of Oil and Gas Business (mob. tel.: +007 96049147 12, e-mail: zep1945@inbox.ru).

Nikita A. Shostak (Author ID in Scopus: 56572448500) - PhD in Engineering, senior lecturer of the Department of Oil and Gas Business (mob. tel.: +007952 83288 00, e-mail: shostak.inge@mail.ru). The contact person for correspondence.

Запорожец Евгений Петрович - доктор технических наук, профессор кафедры нефтегазового дела (моб. тел.: +007960 49147 12, e-mail: zep1945@inbox.ru). Шостак Никита Андреевич - кандидат технических наук, старший преподаватель кафедры нефтегазового дела (моб. тел.: +007 9528328800 , e-mail: shostak.inge@mail.ru). Контактное лицо для переписки. 


\section{Introduction}

Gas hydrates (hereinafter hydrates) are solid crystalline compounds that form in certain thermobaric conditions from gases and water (vaporous, liquid and solid). Hydrates relate to a class of substances which are not chemical compounds. Hydrates can be natural or manmade. Natural hydrates are one of the forms in which gas occurs in the interior of the earth. Estimated natural gas reserves in hydrated state approximate $2 \cdot 10^{16} \mathrm{~m}^{3}$. Russia accounts for $10^{14}-10^{15} \mathrm{~m}^{3}$. Hydrates are a promising source of hydrocarbon gas.

The role of manmade hydrates in oil and gas industry is mainly negative. Hydrate generation in bottom-hole zones and wellbores complicates hydrocarbon production. In oil and gas collection systems under certain conditions of temperature and pressure hydrates deposit on the walls of the pipes and increase their hydraulic resistance, thereby increasing energy consumption. Presence of hydrates in streams of produced fluid extracted from the interior of the earth increases the wear of production headers, reducing their useful life. In hydrocarbon field preparation systems (heat exchanging equipment, separators, pressure reducing valve flow parts, throttle devices, ejectors) hydrate deposition degrades technological processes. Hydrate formation in machinery or collection and treatment systems leads to accidents. Hydrates deposition in pipeline transport reduces its effectiveness. Deposits result in increase of local hydraulic resistance and increase of energy costs required for pumping of the transported medium.

To eliminate manmade hydrates and produce gas from natural hydrates, it is necessary to know the basics of their formation.

The history of hydrate formation study accounts for over 235 years. The authors have analyzed the experimental research and practical applications in the area for the period from 1780 to date and described their findings in [1], based on 1150 literary references. Hydrate formation research is tightly connected to the exploration of natural hydrates reserves, prevention and liquidation of manmade hydrates, targeting of natural hydrates accumulation areas in the course of exploration of new fields and identification of hydrate-hazardous areas in the process of production, collection, preparation and pipeline transportation of hydrocarbons.

In order to solve these tasks, it is necessary to study hydrate formation in natural and technical systems. Based on systematization and analysis of scientific data, the authors have identified a number of regularities of hydrate formation from single-and multicomponent gases as described below.

\section{Hydrate formation from single-component gases}

Hydrate formation depends on the nature of gas, as well as temperature and pressure in the "gas-water" system. Figure 1 presents diagrams of phase states of the system containing some of the individual gases and water (distilled). Hydrate formation is influenced by presence of admixtures in the water. Salts and alcohols normally reduce hydrate formation temperature; type of surfactant determines temperature decrease or increase.
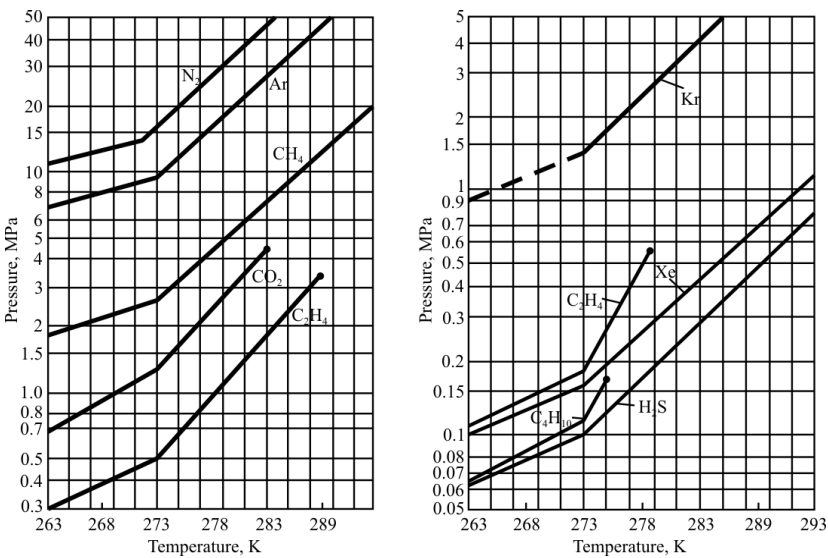

Figure 1. Phase state diagrams of water and hydratescomponents of natural and oil gases

Hydrate forming system can assume following states: gas - fluid water (at $T>273.15 \mathrm{~K}$ ), gas-ice (at $T \leq 273.15 \mathrm{~K}$ ) and crystalline - hydrate. Crystalline hydrate contains water and gas, their quantity depending on the molecular weight of the latter. For instance, $1 \mathrm{~m}^{3}$ of methane hydrate $\left(\mathrm{CH}_{4} \cdot 6 \mathrm{H}_{2} \mathrm{O}\right)$ contains approximately $0.8 \mathrm{~m}^{3}$ water and $160 \mathrm{~nm}^{3}$ gas phase [2].

Hydrates of individual gases can form various crystal lattices: cubic (CS), hexagonal (HS), tetragonal (TS) etc. [2]. Components of natural and oil gases (methane, ethane, propane, isobutane, 
nitrogen, hydrogen sulfide, carbon dioxide, oxygen, argon, xenon) form two structures of crystal lattices - CS-I and CS-II (Figure 2).

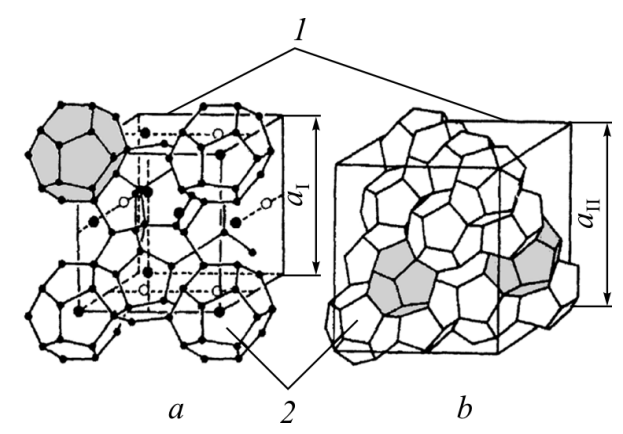

Figure 2. Unit cells structures of hydrate crystal lattices: $a$ - CS-I; $b$ - CS-II; 1 - crystal lattice cell; 2 - hydrate cavity; $a_{\mathrm{I}}, a_{\mathrm{II}}-$ geometrical parameter of CS-I and CS-II structures crystal lattice cells. Gray areas are cavities which are occupied by a molecule of water each. Blank cavities contain a molecule of gas

Hydrate formation proceeds as follows. At certain thermobaric conditions of hydrate formation in "gas - fluid water" system, hydrate cavities consisting of ice-like associates of water molecules initially form around individual molecules of gas and water vapors at steady state with its fluid phase. As an example, Figure 3 shows processes of formation of such cavities around a molecule of methane $(a, b)$ and ethane $(c$, $d$ ). Each cavity contains only one molecule of gas. Cavities with a molecule of water vapor may form. The molecule confined inside the cavity cannot spontaneously leave it. This molecule association is a strong structure.

Depending on the size of gas molecules, cavities of two types (small and large) form (Figure 4), which later become a part of crystalline structures (CS-I and CS-II).

Dodecahedral cavities $D$ and $D^{\prime}$ are normally referred to as small, while the rest of them $(T, T$, $P, H, E)$ - as large.

$\mathrm{CH}_{4}, \mathrm{Ar}, \mathrm{H}_{2} \mathrm{~S}$ molecules with relatively small typical size are trapped by all types of cavities starting from $D$ and $D^{\prime} ; \mathrm{C}_{2} \mathrm{H}_{6}, \mathrm{CO}_{2}$ molecules by $T$-cavities, larger $\mathrm{C}_{3} \mathrm{H}_{8}, \quad i-\mathrm{C}_{4} \mathrm{H}_{10}, \quad n-\mathrm{C}_{4} \mathrm{H}_{10}$ molecules - by $H$-cavities. Very large molecules are only trapped by $E$-cavities. Sizes of gas hydrate forming molecules, types of cavities and crystal lattices are shown as a diagram in Figure 5 [3].

In the course of formation of each of the hydrate cavities, heat energy is produced in the amount that is a total of energy of water fluid phase transition to ice-like associates and heat from gas and water vapor trapping.

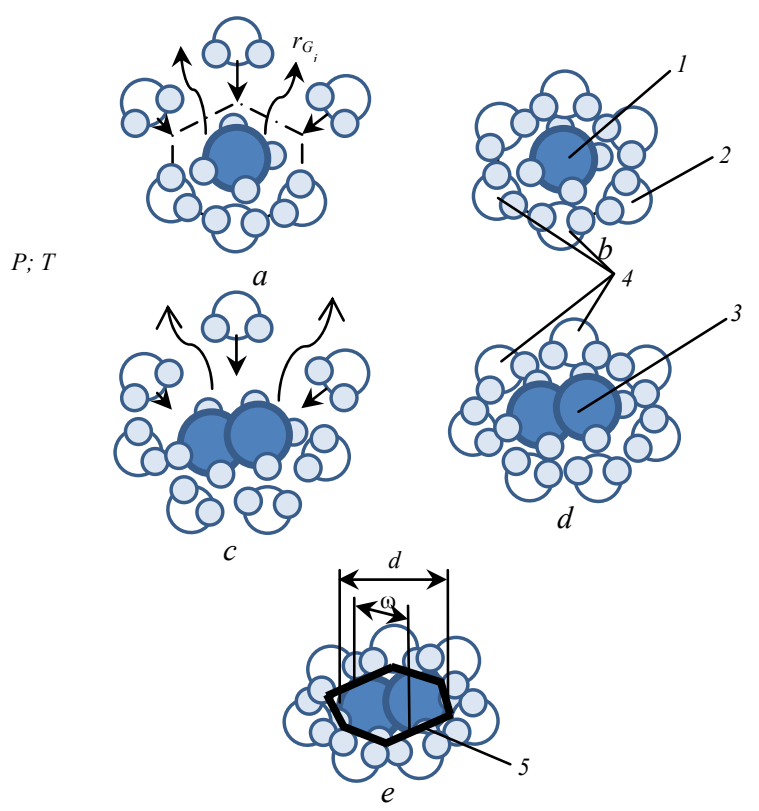

Figure 3. Processes of hydrate cavities formation from methane molecules $(a, b)$ and ethane molecules $(c, d)$; $e$ - formed hydrate ethane cavity: 1 - methane molecule; 2 - water molecule; 3 - ethane molecule; 4 - water molecules ice-like associates; 5 - "window"; $d$ - typical molecule size; $\omega$ - typical "window" size $(d>\omega) ; P, T-$ pressure and temperature of gas-water system; $r_{G_{i}}$ - energy produced in the process of gas trapping by a singular cavity

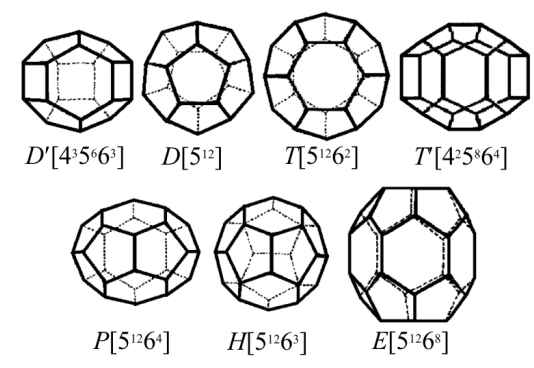

Figure 4. Hydrate cavity varieties based on X-ray structure analysis data

( $m_{i}^{\gamma_{i}}$, where $m_{i}-$ number of edges; $\gamma_{i}$ - number of facets, e.g. for $b$-cavity $m=5, \gamma=12$ )

Transition heat energy is equal to ice generation heat that is directly proportional to the number of water molecules per one molecule of gas (or water vapor).

Heat energy of molecule trapping is equal to their adsorption energy [4]. 
In "gas-ice" system, hydrate cavity forms simultaneously with gas molecule trapping, while the initial solid phase of water (ice) transforms into its ice-like associate. Depending on the nature of gas (molecular weight), the transformation process can be exothermic or endothermic [5]. Trapping of molecules is an exothermic process; heat energy produced in its course is equal in value to the adsorption heat.

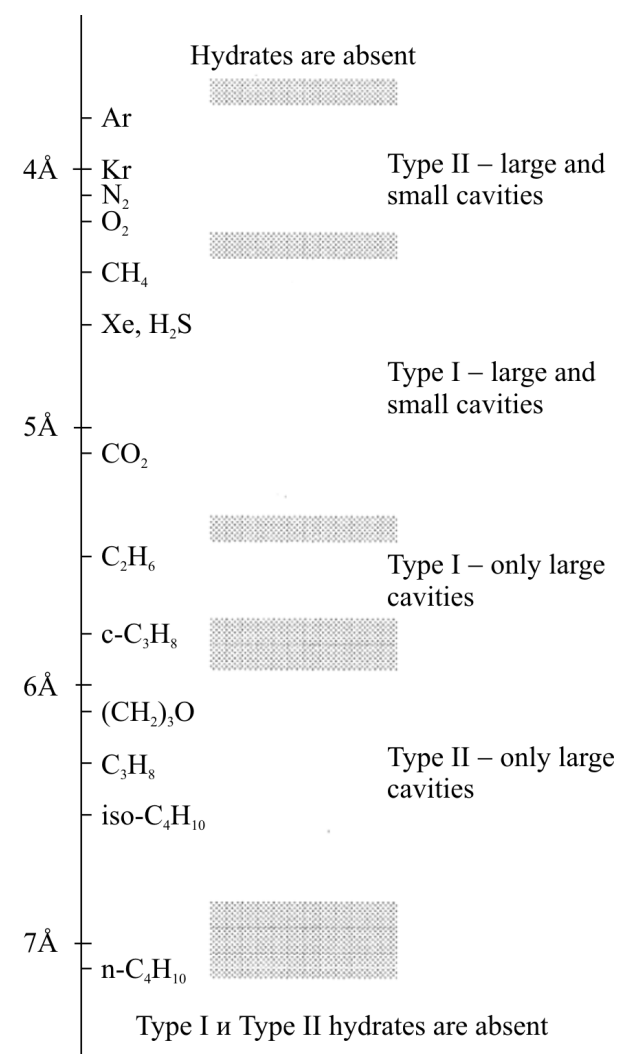

Figure 5. Hydrate forming gases molecule size diagram

Since the quantity of heat energy produced in the process of gas molecules or water vapor trapping is equal to their adsorption energy, the authors assume [6] that this process can be compared to adsorption process. Therefore in the course of hydrate formation process study it is permissible to use the key provisions of Langmuir's adsorption model.

In the process of forming of various structure types from crystal lattice hydrate cavities (see, e.g. Figure) crystallization energy is produced.

The described hydrate formation process is schematically presented in Figure 6.

Hydrate growth rate depends on the intensity of heat discharge as it is produced in the course of ice-like associates forming, as well as molecules trapping in hydrate cavities and crystalline structures forming (see Figure 6). Depending on the rate of heat removal from the hydrate forming system, hydrate forming time increases or reduces. Heat removal normally occurs: through the wall, in case of isenthalpic expansion (Joule-Thompson effect) of gas containing water in vaporous or dispersed state, e.g. in orifices or union; at isentropic (adiabatic) expansion of gas containing water in vaporous or dispersed states, e.g. in nozzles and expansion valves.

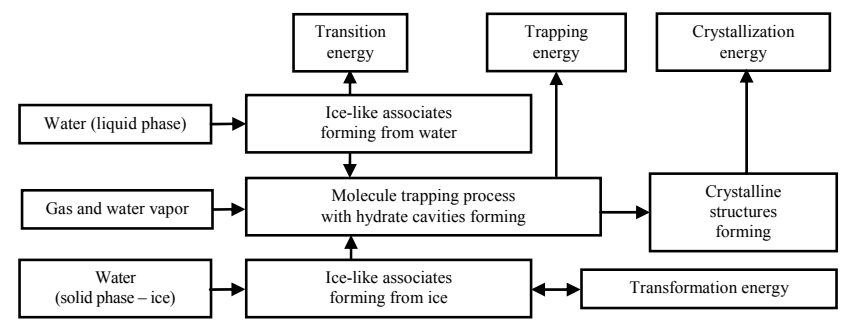

Figure 6. Chart of hydrate formation from single-component gas

The intensity of heat removal directly depends on the area of interphase contact between gas and water or ice (Figure 7), temperature gradient between the forming hydrate and heat absorbing system, as well as on the pressure. In practical terms, the increase of interphase contact area is achieved via agitation of interfacing phases, their blending, dispersing, exposure to vibration etc. [7]. In these circumstances, heat transfer factor increases (Figure 8).

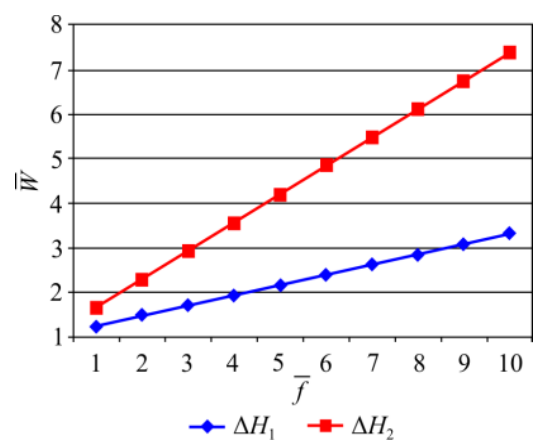

Figure 7. Dependence between relative methane hydrate growth rate on variation of relative contact area at supercooling degree $\Delta T=T_{e q}-T_{\text {refr }}=3 \mathrm{~K}$ in steady-state conditions: $\bar{W}$ - hydrate relative growth rate, $\bar{W}=W_{i} / W_{0}\left(W_{0}=0.0005 \mathrm{~mole} / \mathrm{s}\right)$; $\bar{f}$ - relative contact area, $\bar{f}=f_{i} / f_{0}\left(f_{0}=1 \mathrm{~m}^{2}\right)$;

$\Delta H_{1}$ - heat of hydrate forming from water; $\Delta H_{2}$ - heat of hydrate forming from ice 


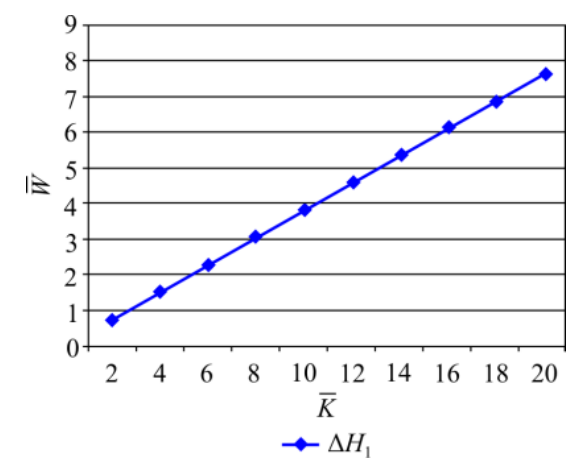

Figure 8. Dependence of methane hydrate relative growth rate on the relative value of heat transfer factor in the event of immediate contact in "gaswater" system: $\bar{W}$ - methane hydrate relative growth rate, $\bar{W}=W_{i} / W_{0}\left(W_{0}=0.00015 \mathrm{~mole} / \mathrm{s}\right)$; $\bar{K}$ - relative heat transfer factor value, $\bar{K}=K_{i} / K_{0}$ $\left(K_{0}=1 \mathrm{~W} /\left(\mathrm{m}^{2} \cdot \mathrm{deg}\right) ; \Delta H_{1}-\right.$ heat of hydrate forming from water

Minimal heat transfer factors are observed at steady-state conditions when hydrate forming system is motionless. Therefore in steady-state conditions low hydrate forming rates have been measured, e.g. at $5.0 \mathrm{MPa}$ pressure and $7{ }^{\circ} \mathrm{C}$ temperature, $100 \mathrm{ml}$ gas turn into hydrate in $2.6 \mathrm{~h}$; at the same temperature and 7.0 MPa pressure - in $1 \mathrm{~h}$; at $-2{ }^{\circ} \mathrm{C}$ and $7.0 \mathrm{MPa}-$ in $0.5 \mathrm{~h}[8,9]$.

Heat transfer factor value can be correlated to the number of rotations of reactor mixer used for research of hydrate forming and growth. Dependence between relative heat transfer factor $\bar{K}$ and number of rotations of the mixer is shown in Figure 9 [5].

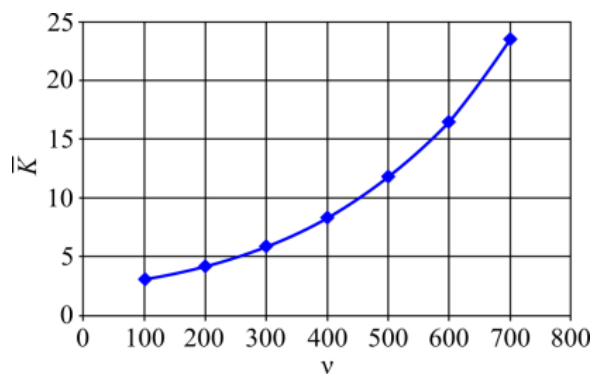

Figure 9. Dependence between relative heat transfer factor and number of rotations of the reactor mixer: $\bar{K}$ - relative heat transfer factor; $v$ - number of mixer rotations

Evidence exists that it is possible to accelerate hydrate growth by applying physical force (acoustic, electromagnetic, photon, high frequency). However, any of such forces cause energy inflow to hydrate which, on the contrary, is supposed to result in deceleration of growth.

The paradoxical phenomenon of hydrate forming and growth is observed upon treatment with some of the anti-hydrate reactants. In the presence of minor amounts (0.5-3 mole \%) of alcohols (lower aliphatic alcohols from methanol to propanol, glycols), hydrate formation speeds up $[2,10-13]$. The phenomenon is explained by the authors [10] by increasing reciprocal solubility of hydrate-forming components. Others assume [11] that alcohol molecules become embedded in the solution and serve as "germs" for clathrate hydratetype structure. Study of water-methanol solutions structure by means of neutron diffractometry methods [14] has determined the existence of a membrane composed of water molecules around the methyl group of methanol molecule at a distance of approximately $0.37 \mathrm{~nm}$ from carbon atom. Methanol concentration increase in the solution leads to redistribution (increase) of hydrogen connections between the molecules of water and alcohol in the solution. Methanol forms own supramolecular structures with water and becomes a competitor for gas in terms of hydrate forming. As a consequence, methanol concentration increase decelerates hydrate forming process.

Adding of $0.05-1.00 \mathrm{~g} / 1$ surfactants in water solutions produces an effect of step-like increase in the hydrate forming process (for some gases by a factor of ten and more) $[15,16]$. The explanation for this effect is that the presence of surfactants causes formation of porous hydrates, in which capillary forces cause influx of fluid to the hydrate formation interface, facilitating continuous renovation of "fluid-gas" interphase surface and hydrates intensive growth. Hydrates forming and growth rate increase in surfactant solution is also explained $[17,18]$ by micelles formation, in which colloidal dissolution (solubilization) of gas occurs. In this case hydrate forming occurs not only on the "fluid-gas" interface but also in bulk of micellar solution, resulting in increased rate of hydrate forming. However it has to be mentioned that, just like in case of alcohol solutions, certain watersoluble surfactants can decelerate hydrate formation [2]. 


\section{Hydrate formation from multicomponent gas}

Natural and oil (associated) gases extracted from wells are multicomponent blends. Multicomponent composition causes certain peculiarities in hydrate forming from such gases. The key difference is that not each component of the mix is able to participate in hydrate formation.

According to the Gibbs phase rule, CS-I and CS-II structures can exist both separately (CS-I or CS-II), and in combination (CS-I and CS-II) [2]. Based on this phenomenon, hydrate bulk may consist of uniform structures or their blend (Figure 10).

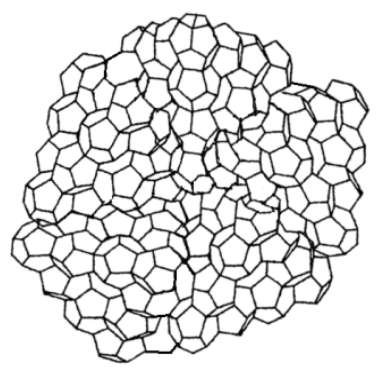

Figure 10. Multicomponent gas hydrate consisting of CS-I and CS-II structures (cavity occupation is not shown)

Conditions of mixed hydrates formation are largely influenced by concentration of individual components. For instance, thermobaric conditions of hydrate formation for binary methane-ethane and methane-propane mixtures available from experiment are shown in Figure 11, $a, b$.
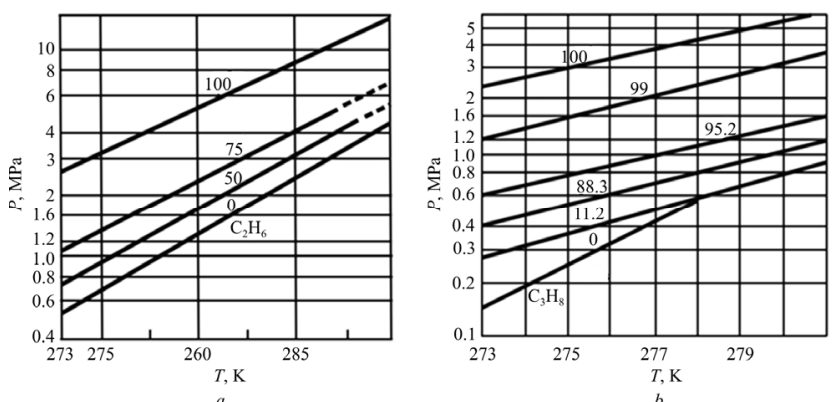

Figure 11. Hydrate formation conditions in "methane-ethane-water" system $(a)$ and "methane-propane-water" system $(b)$ based on data from [19]. Figures next to curves are molar content of methane in gas mixture, $\%$
Phase equilibrium curves for $\mathrm{CH}_{4}$ and $\mathrm{C}_{2} \mathrm{H}_{6}$ or $\mathrm{CH}_{4}$ and $\mathrm{C}_{3} \mathrm{H}_{8}$ mixtures show that hydrates form at lower pressure and higher temperature when ethane and propane are added.

In order to determine the equilibrium conditions for natural and oil gas hydrates formation, it is common to use a nomogram depicted in Figure 12 [20]. Knowing gas density (relative to air) and pressure, it helps to determine the threshold temperature for hydrate formation.

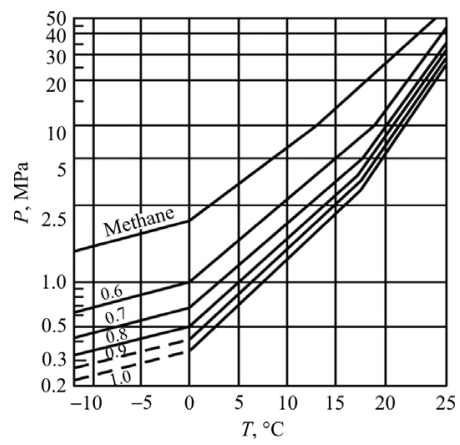

Figure 12. Hydrate forming conditions for multicomponent gases of varying densities [18].

Figures stand for gas density relative to air

Normally hydrate formation temperature directly correlates with gas density; however, it is important to know that there are exceptions. Natural gas with low density can form hydrates at higher temperatures than natural gas with higher density. If natural gas density is influenced by components that cannot form hydrates, than its hydrate forming temperature is lower.

\section{Summary}

To conclude, this paper discusses hydrate formation process from single- and multicomponent natural and oil gases occurring in natural and manmade systems.

\section{Acknowledgement}

The research was conducted with financial support of the Russian foundation for fundamental research in the scope of scientific research project No. 16-38-60108.

\section{References}

1. Zaporozhets E.P., Shostak N.A. Gidraty: monografiia [Hydrates: monograph]. Krasnodar: Iug, $2014,460 \mathrm{p}$
2. Byk S.Sh., Makogon Iu.F., Fomina V.I. Gazovye gidraty [Gas hydrates]. Moscow: Nedra, 1980, $296 \mathrm{p}$. 
3. Hughes T.J. Plug formation and dissociation of mixed gas hydrates and methane semi-clathrate hydrate stability: a thesis submitted in partial fulfilment of the requirements for the degree of doctor of philosophy in chemical and process engineering by University of Canterbury, Christchurch, 2008, 236 p.

4. Davidson D.W. Clathrate hydrates. In: Water. A comprehensive treatise. Ed. by F. Franks. Vol. 2. Water in crystalline hydrates. Aqueous solution of simple nonelectrolytes. N.-Y.: Plenum Press, 1973, pp.115-234.

5. Shostak N.A. Modelirovanie obrazovaniia i dissotsiatsii gidra-tov pri razrabotke i ekspluatatsii neftianykh i gazovykh mestorozhdenii [Modelling of the formation and dissociation of hydrates during oil and gas fields' production]: dis. ... kand. tekhn. nauk. Krasnodar, 2014, 118 p.

6. Zaporozhets E.P., Shostak N.A. Adsorbtsionnoenergeticheskaia mo-del' kinetiki obrazovaniia i dissotsiatsii gazovykh gidratov [Adsorption-energy model of the kinetics of formation and dissociation of gas hydrates]. Teoreticheskie osnovy khimicheskoi tekhnologii, 2015, vol. 49, no.3, pp.322-328.

7. Zaporozhets E.P., Shostak N.A. Faktory, vliiaiushchie na skorost' rosta gazovykh kristallogidratov [Factors that affect the growth rate of gas crystalline hydrates]. Neftepromyslovoe delo, 2015, no.1, pp.49-56.

8. Istomin V.A., Iakushev V.S. Gazovye gidraty v prirodnykh us-loviiakh [Gas hydrates in natural conditions]. Moscow: Nedra, 1992, 236 p.

9. Vysnauskas A., Bishnoi P.R. Kinetics of ethane hydrate formation. Chemical Engineering Science, 1985, vol.40, pp.299-303. DOI: 10.1016/0009-2509(85)80070-1.

10. Krasnov A.A., Klimenok B.V. Issledovanie kinetiki protsessov klatratsii metodom izokhron [Processes' kinetics study by the isochronous klatration methods]. Neftekhimiia, 1973. vol.13, no.4, pp.592-595.

11. Malenko E.V. Issledovanie uslovii obrazovaniia i razrusheniia gidratov prirodnogo gaza i izuchenie ingibiruiushchego vliianiia neelektroli-tov [Research of formation and destruction conditions of the natural gas hydrates and study the inhibitory effect of non-electrolytes]: dis. ... kand. khim. nauk. Moscow, 1979, 168 p.
12. Barrer R.M., Ruzicka D.J. Non-stoichiometric clathrate compounds of water. Part 4. Kinetics of clathrate phases. Transactions of the Faraday Society, 1962, vol.58, pp.2262-2271. DOI: 10.1039/tf9625802262.

13. Yousif M.H., Dorshow R.B., Young D.B. Testing of hydrate kinetic inhibitors using laser light scattering technique. Annals of the New York Academy of Sciences, 1994, vol.715, pp.330-340. DOI: 10.1111/j.1749-6632.1994.tb38845.x.

14. Soper A.K., Finney J.E. Hydration of methanol in aqueous solution. Phys. Rev. Eet., 1993, vol.71, no.26, pp.4346-4349. DOI: 10.1103/PhysRevLett.71.4346

15. Burmistrov A.G. Issledovanie fazovykh ravnovesii slozhnykh ge-terogennykh sistem v protsessakh promyslovoi obrabotki prirodnogo gaza, so-derzhashchego neuglevodorodnye komponenty [Study of phase equilibria in complex heterogeneous systems in field processing of natural gas containing non-hydrocarbon components]: avtoref. dis. ... kand. tekhn. nauk. Moscow: VNIIGaz, 1981, 22 p.

16. Nesterov A.N. Kinetika i mekhanizm gidratoobrazovaniia gazov $\mathrm{V}$ prisutstvii poverkhnostnoaktivnykh veshchestv [Kinetics and mechanism of gashydrates formation in the presence of surfactants]: dis. ... d-ra khim. nauk. Tiumen', 2006, 280 p.

17. Lin W. et al. Effect of surfactant on the formation and dissociation kinetic behaviour of methane hydrate. Chem. Eng. Sci., 2004, vol.59, pp.4449-4455. DOI:10.1016/j.ces.2004.07.010.

18. Gnanendran N., Amin R. The effect of hydrotropes on gas hydrate formation. J. Petrol. Sci. Eng., 2003, vol.40, pp.37-46. DOI: 10.1016/S0920-4105(03)00082-2.

19. Holder G.D., John V.T. Thermodynamics of multicomponent hydrate forming mixtures. Fluid Phase Equil., 1983, vol.14. pp.353-361. DOI: 10.1016/03783812(83)80141-1.

20. Degtiarev B.V., Bukhgalter E.B. Bor'ba s gidratami pri ekspluata-tsii gazovykh skvazhin $\mathrm{V}$ severnykh usloviiakh [Fight against hydrates in the operation of gas wells in northern conditions]. Moscow: Nedra, 1976, 198 p.

\section{Список литературы}

1. Запорожец Е.П., Шостак Н.А. Гидраты: монография. - Краснодар: Юг, 2014. - 460 с.

2. Бык С.Ш., Макогон Ю.Ф., Фомина В.И. Газовые гидраты. - М.: Недра, 1980. - 296 с.

3. Hughes T.J. Plug formation and dissociation of mixed gas hydrates and methane semi-clathrate hydrate stability: a thesis submitted in partial fulfilment of the requirements for the degree of doctor of philosophy in chemical and process engineering by University of Canterbury. - Christchurch, 2008. - 236 p.

4. Davidson D.W. Clathrate hydrates // Water. A comprehensive treatise / Ed. F. Franks. Vol. 2. Water in crystalline hydrates. Aqueous solution of simple nonelectrolytes. - N.-Y.: Plenum Press, 1973. - P. 115-234.
5. Шостак Н.А. Моделирование образования и диссоциации гидратов при разработке и эксплуатации нефтяных и газовых месторождений: дис. ... канд. техн. наук. - Краснодар, 2014. - 118 с.

6. Запорожец Е.П., Шостак Н.А. Адсорбционноэнергетическая модель кинетики образования и диссоциации газовых гидратов // Теоретические основы химической технологии. - 2015. - Т. 49, № 3. C. 322-328.

7. Запорожец Е.П., Шостак Н.А. Факторы, влияющие на скорость роста газовых кристаллогидратов // Нефтепромысловое дело. - 2015. - № 1. - С. 49-56.

8. Истомин В.А., Якушев В.С. Газовые гидраты в природных условиях. - М.: Недра, 1992. - 236 с. 
9. Vysnauskas A., Bishnoi P.R. Kinetics of ethane hydrate formation // Chemical Engineering Science. - 1985. - Vol. 40. - P. 299-303. DOI: $10.1016 / 0009-2509(85) 80070-1$.

10. Краснов А.А., Клименок Б.В. Исследование кинетики процессов клатрации методом изохрон // Нефтехимия. - 1973. - Т. 13, № 4. - С. 592-595.

11. Маленко Э.В. Исследование условий образования и разрушения гидратов природного газа и изучение ингибирующего влияния неэлектролитов: дис. ... канд. хим. наук. - М., 1979. - 168 с.

12. Barrer R.M., Ruzicka D.J. Non-stoichiometric clathrate compounds of water. Part 4. Kinetics of clathrate phases // Transactions of the Faraday Society. - 1962. Vol. 58. - P. 2262-2271. DOI: 10.1039/tf9625802262.

13. Yousif M.H., Dorshow R.B., Young D.B. Testing of hydrate kinetic inhibitors using laser light scattering technique // Annals of the New York Academy of Sciences. - 1994. - Vol. 715. - P. 330-340. DOI: $10.1111 /$ j.1749-6632.1994.tb38845.x.

14. Soper A.K., Finney J.E. Hydration of methanol in aqueous solution // Phys. Rev. Eet. 1993. - Vol. 71, № 26. - P. 4346-4349. DOI: 10.1103/PhysRevLett.71.4346
15. Бурмистров А.Г. Исследование фазовых равновесий сложных гетерогенных систем в процессах промысловой обработки природного газа, содержащего неуглеводородные компоненты: автореф. дис. ... канд. техн. наук. - М., 1981. - 22 с.

16. Нестеров А.Н. Кинетика и механизм гидратообразования газов в присутствии поверхностно-активных веществ: дис. ... д-ра хим. наук. Тюмень, 2006. - 280 c.

17. Effect of surfactant on the formation and dissociation kinetic behaviour of methane hydrate / W. Lin [et al.] // Chem. Eng. Sci. - 2004. - Vol. 59. - P. 44494455. DOI: $10.1016 /$ j.ces.2004.07.010.

18. Gnanendran N., Amin R. The effect of hydrotropes on gas hydrate formation // J. Petrol. Sci. Eng. - 2003. - Vol. 40. - P. 37-46. DOI: $10.1016 / \mathrm{S} 0920-4105(03) 00082-2$.

19. Holder G.D., John V.T. Thermodynamics of multicomponent hydrate forming mixtures // Fluid Phase Equil. - 1983. - Vol. 14. - P. 353-361. DOI: 10.1016/0378-3812(83)80141-1.

20. Дегтярев Б.В., Бухгалтер Э.Б. Борьба с гидратами при эксплуатации газовых скважин в северных условиях. - М.: Недра, 1976. - 198 с.

Please cite this article in English as:

Zaporozhets E.P., Shostak N.A. Features of single- and multicomponent gas hydrates formation. Bulletin of PNRPU. Geology. Oil \& Gas Engineering \& Mining, 2016, vol.15, no.20, pp.232-239. DOI: 10.15593/2224-9923/2016.20.3

Просьба ссылаться на эту статью в русскоязычных источниках следующим образом:

Запорожец Е.П., Шостак Н.А. Особенности гидратообразования одно- и многокомпонентных газов // Вестник Пермского национального исследовательского политехнического университета. Геология. Нефтегазовое и горное дело. - 2016. - Т.15, №20. C.232-239. DOI: $10.15593 / 2224-9923 / 2016.20 .3$ 